\title{
2020 Stimulus Coronavirus Aid, Relief and Economic Security Act: Comparative Analysis of President Roosevelt's New Deal Programs and President Obama's American Recovery and Reinvestment Act of 2009
}

\author{
Gbolahan S. Osho ${ }^{1}$, Michael Adams², Quonna Coleman² \& Matthew Uwakonye ${ }^{3}$ \\ 1Prairie View A\&M University, USA \\ ${ }^{2}$ Texas Southern University, USA \\ ${ }^{3}$ Grambling State University, USA \\ gsosho@pvamu.edu
}

\begin{abstract}
America is facing an economic disaster and is in need of federal relief to remain leading nation. Is America currently facing another Great Depression? In the 1930s the United States suffered from an economy downturn; the stock market crashed, spending declined, there was a drop in production, jobs were lost, bills went unpaid, and the market for produce reduced. President Franklin D. Roosevelt implemented the New Deal Programs to recover the economic damage of the United States. President Barack Obama inherited a stressed economy from former President George W. Bush with a national debt of $\$ 10.627$ trillion. As President Roosevelt once did, President Obama is now working toward a plan to recover the damaged United States economy? The uncontainable depression later referred to as the Great Depression attacked the economy of the United States. In 2007 the United States began to take an economy downtown again. President Franklin D. Roosevelt implemented the New Deal Programs to recover the economic damage of the United States. President Barack Obama inherited a stressed economy from former President George W. Bush with a national debt of $\$ 10.627$ trillion.
\end{abstract}

Keywords: New Deal Programs, Great Depression, American Recovery and Reinvestment Plan.

\section{Introduction}

Wall Street has taken a turn for the worst, American citizens are losing their homes, American Corporations are threaten to file bankruptcy, the value of the American dollar is declining and the National debt is at an alltime high. America is facing an economic disaster and is in need of federal relief to remain leading nation. Is America currently facing another Great Depression? In the 1930s the United States suffered from an economy downturn; the stock market crashed, spending declined, there was a drop in production, jobs were lost, bills went unpaid, and the market for produce reduced. The uncontainable depression later referred to as the Great Depression attacked the economy of the United States. It revealed that the economic interrelatedness implied that no area of the economy was insusceptible to negative impact. In 2007 the United States began to take an economy downtown again. The stock market is suffering, spending has decreased, the cost of produced has increase, and as of March 2009, 8.5\% of American Citizens suffer from unemployment. President Franklin D. Roosevelt executed the New Deal Programs to recover the economic damage of the United States. President Barack Obama inherited a stressed economy from former President George W. Bush with a national debt of $\$ 10.627$ trillion. As President Roosevelt once did, President Obama is now working toward a plan to recover the damaged United States economy.

The purpose of this study is to examine and identify the similarities and differences in the Great Depression of 1929 and the current United States economic depression. By conducting a research of this magnitude, one will be able to identify whether the methods used by President Roosevelt to address the Great Depression can provide President Obama with a road map or a lessons learned structure. The study will provide governmental officials and economic specialist with an insight on economy stressors that break the United States economy and threaten its stability as the leading nation. The common foundation shared by President Roosevelt and President Obama is that both presidents entered into their Presidency working and striving to clean up an economic disaster what was not created on their watch. When the first hundred day of his Presidency President Roosevelt enacted new programs to provide relief to the American people and address the unprecedented political capital. "Throughout the nation men and women, forgotten in the political philosophy of Government, look to us here for guidance and for more equitable opportunity to share in the distribution of national wealth. I pledge myself to a new deal for the American people. This is more than a political campaign. It is a call of arms" (The Roosevelt Week). 
In Remarks of Senator Barack Obama: The Common Stake in America's Prosperity address, President Obama opened his address with reflects to the actions taken by President Roosevelt to address the Great Depression. "Roosevelt called for a "re-appraisal of values." He suggested that in the United States: "our right to live must also include the right to live comfortably; that government must favor no small group at the expense of all its citizens; and that in order for us to prosper as one nation, "the responsible heads of finance and industry, instead of acting each for himself, must work together to achieve the common end" (Remark of Senator Barack Obama..., 1)".

President Obama felt that the American vision to restore our economic downturn required much more than just replacing a failed President. Restoration and renewal had to be incorporated into the lives of American Businesses and American people. Each individuals needs to work collective to restore the economy as during the Great Depression the United States realized all things working together affects the success or failure of the economy. President Obama is approaching his first hundred days in office and he too has taken efforts to address the outcry of the American people and the inherited national debt.

The New Deal: The programs presented a mean to reverse the economic disaster; it provided relief with a broad program that involved a level of policy planning and coordination that was beyond the capacity of the Congress. The goal of this complex package of economic programs was to provide relief to unemployed individuals, reform businesses and their financial practices and promote recovery during the economic depression. The National Recovery Administration and the Public Works Administration implemented the National Industry Recovery Act (NIRA) of 1933 to create jobs through massive public works efforts and coordinate actions of major industries. "However, the New Deal was opposed by economic conservatives (who accused Roosevelt of leading the nation down the road of communism) and by justices of the Supreme Court. In Schechter Poultry Corp v. United States (1935), the Court invalidated the Recovery Act by a 5-4 vote, ruling that it usurped powers reserved to the states" (Patterson, 82).

President Roosevelt encountered various problems and negative feedback from other branches of the government and citizens when attempting to address the economic issues of the nation. He continued to keep his focus and stress the importance of the New Deal Programs. The most notable programs implemented by President Roosevelt under the New Deal were as follows: 1. Federal Deposit Insurance Corporation (FDIC), which insured deposits in banks up to $\$ 5,000 ; 2$. Civil Works Administration (CWA), which provided temporary jobs to millions of the unemployed and 3. National Labor Relations Act (NLRA), which set up the National Labor Relations Review Board to supervise labor-management relations. President Roosevelt implemented a number of other programs, most of which still exist today. The existing programs have been modified as the centuries and the nation began to globalize, but they still serve their intended purposes.

American Recovery and Reinvestment Plan: President Obama has received both negative and positive feedback from other branches of the government and supporters. He is focused on addressing the economic damaged that has impacted the United States over recent years. President Obama introduced the American Recovery and Reinvestment Act of 2009. "The plan invests in clean energy, health care, education and infrastructure; cuts taxes for American families and businesses; and helps protect the most vulnerable families from economic harm during the recession. This plan will also break from conventional Washington approaches to spending by ensuring that public dollars are invested effectively and that the economy recovery package is fully transparent and accountable to the American people" (American Recovery and Reinvestment Plan, 1). President Obama's plan was enacted into legislation on February 17, 2009 and became the American Recovery and Reinvestment Act of 2009. The Act is much more encompassing then the Economic Stimulus Act of 2008 that principally provided taxpayers with a rebate check.

The American Recovery and Reinvestment Act comprise federal tax relief, extension of unemployment benefits, social welfare provisions, domestic spending in education, health care, infrastructure and energy sectors. In addition to the economic recovery the act also include non-economic related relief, which includes long-term efforts to study the effectiveness of medical treatment and limitation on executive responsibility and compensation in federally aiding banks. President Obama's plan is encompasses many of the attributes included in President Roosevelt's plan, except are has been expanded to encompass the ever-changing economic aspects of the $21^{\text {st }}$ century. "We certainly do not face a test of the magnitude that Roosevelt's 
generation did. But we are tested still. We meet at a time when much of Wall Street is holding its collective breath. Here at the NASDAQ and all across America, the tickers are being watched with heightened anxiety and considerable uncertainty. There is much anticipation about tomorrow's meeting of the Fed, and with each new day, there is hope that the headlines will bring better news than the last" (Remarks of Senator Barack Obama, 2).

\section{Literature Review}

There have been a number of studies conducted by journalist, novelist, essayist; historians and economist have contributed to the general understanding of the past and present economy of the United States. The authors analyzed have collectively concluded economy of the United States plays a major role in the nation's ability to remain dominant, the resolves of uncontrolled and use less spending of federal dollars, and the need of more federal rules and regulations that govern the American Businesses. Each author offers a descriptive image of how the works of President Roosevelt aided the United States in economic recovery in both negative and positive aspects. In addition to how the efforts of President Obama will affect America in the long run. The New Deal Programs implemented by President Roosevelt addressed many of the issues the United States faced in the economy, but he still felt more needed to be done. President Roosevelt wrote a document entitled "An Economic Bill of Rights," which was recommendation for Congress to adopt in order maintain a fair and stable economy and concentrate all of the nation's energy and resources on winning the war. In 1944 after many of the New Deal Programs were implemented there still need to stabling focus that kept the economy afloat. President Roosevelt outlined a total of five recommendations among which included the following: 1 . realistic tax law, 2. a continuation of the renegotiation of war contracts, 3. a cost of food law, 4. early enactment of the stabilization statue of October 1942, and 5. a national service law.

The realistic law called for the taxation of all unreasonable individual and corporate profit and the reduction of the war. The second recommendation of a continuation of the law for the renegotiation of war contracts suggested the hindrance of excessive profits and assurance of fair prices to the Government. A cost of food law, the third recommendation enabled the administration to a place sensible price floor that farmers may anticipate for their production and placed a price ceiling that consumers have to pay for their food. Fourthly, the early enactment of the stabilization statue of October 1942, as it was due to expire on June 30, 1944. According to Roosevelt if this was not enacted in due time the United States would be a risk of the inability to maintain the integrity of the American dollar. Lastly, the fifth recommendation for the Congress to adopt a national service law, which would have prevented strikes throughout the war and with certain proper expectation with readiness for the war production for necessary needed good and services. President Roosevelt saw the enactment of these recommendations as a necessity, along with the recommendation he suggest that there been a new Bill of Rights. An Economic Bill of Rights that encompassed the changes of the growing nation: "This Republic had its beginning and grew to its present strength, under the protection of certain inalienable political rights - among them the right of free speech, free press, free worship, trial by jury, freedom from unreasonable searches and seizures.

They were our rights to life and liberty." "As our nation has growing size and stature, however-as our industrial economy expanded - these political rights proved inadequate to assure us equality in the pursuit of happiness" (Dolbeare and Cummings, 419). The rights suggested by President Roosevelt spelled security and prosperity for the American people. Among these are as follows: "the right to useful and remunerative job in the industries or shops or farms or mine of the nation; the right of every farmer to raise and sell his products at a return which will give him and his family a decent living; the right of every business man, large and small to trade in an atmosphere of freedom from unfair competition and domination by monopolies at home or abroad; the right of every family to a decent home; the right to adequate medical care and the opportunity to achieve and enjoy good health; the right to adequate protection from the economic fears of old age, sickness, accident and unemployment; and the right to a good education" (Dolbeare and Cummings 419-420). The suggestion offered by President Roosevelt were presented during a time in which the United States was engaged in war and facing economic issues. This is similar to the state of the United States now. We are currently engaged in war and faced economic issues. The rights outline by President Roosevelt approximately sixty-five years ago is still very relevant in the American economy and in the lives of the American people today. 
This brings about the questions of whether the United States would be facing another economic downturn had the Economic Bill of Rights been enacted. It is important for governmental official to go back and review this documentation, as it will provide value information and minimum guidance. Unfortunately, President Roosevelt did not outline how the rights should be enacted, which means there is still an opportunity for interpretation. Interpretation is exactly a good thing as the United States still faced the relevant problems outlined by President Roosevelt, but there are still new aspects. President Roosevelt laid the foundation; now the Economic Bill of Rights should be revisited and enacted. I believe the rights could contribute to the prevention and/or quicker recovery efforts for future economic downturns. "Faith in America, faith in our tradition or personal responsibility, faith in our institutions, and faith in our institutions, and faith in ourselves demands that we all recognize the new terms of the old social contract" (Remarks of Senator Barack Obama, 1). President Obama presented his economic plan to the nation during his presidential campaign by opening with a quote from President Roosevelt. The quote illustrates President Obama's comprehensive understanding of how the economy works as a whole. The president also realized that during the Great Depression, Americans flourish the more when all things work together interchangeably. In President Obama's address he identifies the consequences and lessons learned from individuals that continuously put their own personal gain ahead of the long-term gain and impact of the American economy.

The Consequences Identified Include: Nearly 2.5 million homeowners could lose their homes and millions others could see a tremendous decline in the value of their homes and the projected cost to investors is nearly $\$ 150$ billion worldwide. Since President Obama address as the senator these numbers have not seen a decrease or a line of stability; the United States is considered to be in a Great Recession. President Obama states: "There are a number of lessons that we must learn from this on going forward. We know that much of this could have been avoided if the market operated with more honesty and accountability. We also know we would have been far better off if there were greater transparency and more information had been available to the American people" President Obama desire to create a sense of transparency in the government for the American people was critical in the passage of the Act. It is the understanding of President Obama that the utilization of the available technologies and methods must be used to open up the federal government and create a new level of transparency. A form of transparency that will change the way business is conducted in Washington and give Americans the chance to participant in government deliberations and decision making.

This was not possible a few years ago. Unfortunately, the honest and accountability of individuals is a difficult attribute to control. When dealing with money or an individual having to face extreme consequences an individual's character can change and honesty and accountability can easily be eliminated from one's character. President Obama utilizes these lessons learned to later assist with his efforts to the American Recovery and Reinvestment Act pushed through Congress. President Obama closes his address with the following quote, "Failure is not an American habit; and in the strength of great hope we must all shoulder our common load" (Remarks of Senator Barack Obama, 8). This too is a quote from President Franklin D. Roosevelt. President Obama sees this as the strength and hope the American government, businesses and people should seek today, and in all the days and months to come. This address illustrates the influential impact the works of President Franklin D. Roosevelt has had on the understanding of President Obama and the direction in which he plans to take action. Authors and Economists, Barry Eichengreen and Kevin $\mathrm{H}$. O'Rourke conduct an analysis of the economy.

In the 1930s and the economy now. In their work entitled, "A Tale of Two Depressions," the authors' conduct and comparative analysis to determine the similarities and differences in the Great Depression and our current economic status. The authors' basic conclusion is that our current economic status is much more than simply a Great Recession, it is even being to surpass the Great Depression. The global economy is presently experiencing a negative disaster known as the COVID-19 that as big as the Great Depression shock of 192930. The request then was whether that policy measure will work. "The Great Depression was a global phenomenon. Even if it originated, in some sense, in the US, it was transmitted internationally by trade flows, capital flows and commodity prices. That said different countries were affected differently. The US is not representative of their experiences." "Our Great Recession is every bit as global, earlier hopes for decoupling in Asia and Europe notwithstanding. Increasingly there is awareness that events haven taken an even uglier turn outside the US, with even larger falls in manufacturing production, exports and equity prices" (Eichengreen and O'Rourke, 1). 


\section{Analysis}

President Roosevelt was able to restore the economy of the United States with the implementation of the New Deal Programs. President Obama is now working toward restoring the failing United States economy once again with the implementation of the American Recovery and Reinvestment Act of 2009. The following statistical analysis will include statistical data collected regarding the similarities and difference in the economic downturn America faced in the 1930s and the downturn we are currently facing in the $21^{\text {st }}$ century. As mentioned in 1929 America show a tremendous decline in spending, there was a drop in production, jobs were lost, bills went unpaid, and the market for produce reduced. The following photo is an illustration of the millions of unemployed individuals standing in line waiting for aid. Many have attempted to comment on the comparison of America then and America now, but according to the authors many have failed to realize that the Great Depression was a global economic downturn. The proceeding graphs and charts will provide comparative analysis on American during the Great Depression and America now.

The two photos above illustrate that many individuals are being heavily impact by the economic downturn now, as they once did during the Great Depression. The illustrates also establish an visual understanding and provide knowledge that the recession in not only affect one individual social class and/or gender, but is affecting the American people as a whole. The following graph depicts a comparison of the current market to all pervious bear markets. According to the graph the current United States market has not reached the lows of the 1929 market crash. However, between 1929 and 1932 the stock market had declined rapidly and continuously over a 150 week time period to $-90 \%$ in pricing. The United States has not reached the $-90 \%$ status, but has reached the half way mark at $-50 \%$ pricing decline over a 76 week time period. Although we have not yet reached the decline experienced in 1929 it appears that our current decline is occurring over a shorten time span then before.

Figure 1: How Far Have We Fallen? Stock Market during the Great Depression and Now

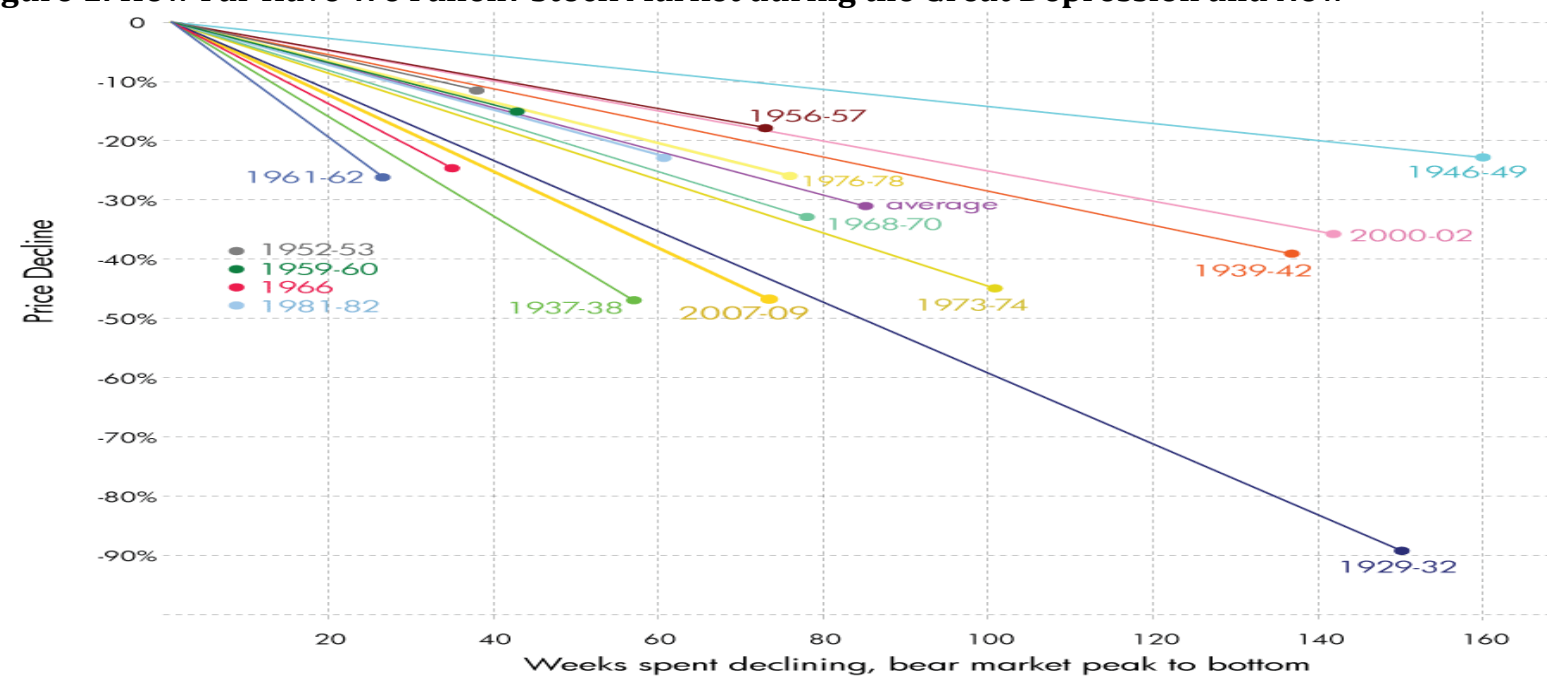

Source: JP Konping Financial Graph \& Art. www.financialgraphhart.com

Figure 2, the nation's inability to stay in line with the granted budget. We come close but there is still a defined different. During the Great Depression era the nation had a negative GDP percentage, which can be considered a contributing factor to the nation's economic downturn. Fortunately, the United States has not received that point in a tremendous amount as in 1942. The problem illustrated in the graph exceeding the granted budget for each fiscal year. The graph above identifies the impacts on the economy on the nations GDP between 1930 and 2009, the next graph illustrates the GDP once the American Recovery and Reinvestment Act of 2009 is implemented and effectively operating. The GDP of the United States is currently at Baseline level, but according to the predictions outlined in graph as the act is implement the GDP will reach it potential over a ten-year time span. Lastly, the following image exemplifies how the funding in the American Recovery and Reinvestment Act of 2009 will be allocated. 
Figure 2: Total and On-Budget Deficits and Surpluses, 1930-2009

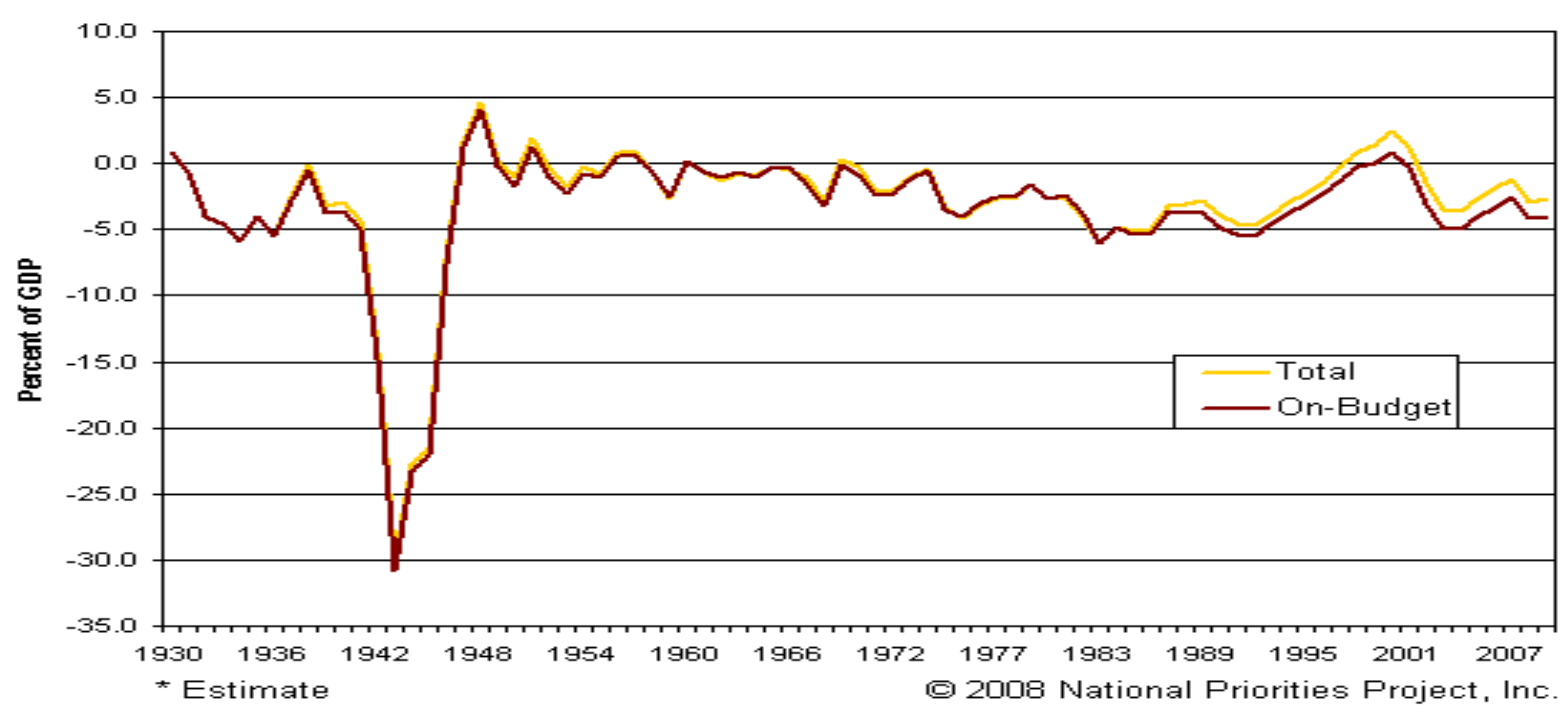

Source: Office of Management and Budget, Budget of the U.S. Government, FY2009, Historical Tables.

The initial tax relief comprised of $\$ 15 \mathrm{~B}$ for infrastructure and science, $\$ 61 \mathrm{~B}$ for protecting the general population, $\$ 25 \mathrm{~B}$ for education and training and $\$ 22 \mathrm{~B}$ for energy. The total funds were $\$ 126 \mathrm{~B}$ for Infrastructure and Science, \$142 B for general population, \$78 B for education and training, and \$65 B for Energy. While state and local fiscal measures were cut and averted for health and education programs but an increase in state and local tax were implemented.

Figure 3: The Impact of the American Recovery and Reinvestment Act of 2009

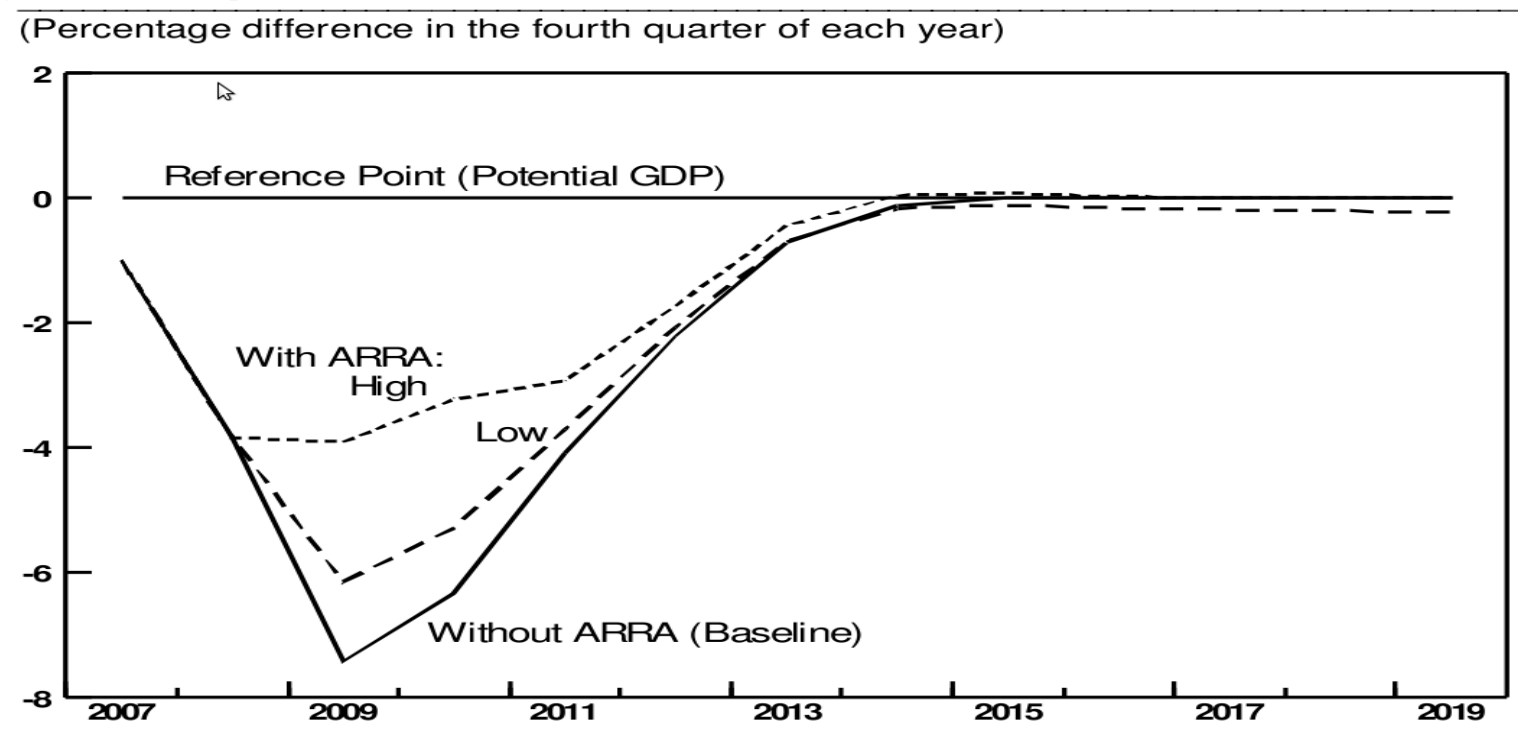

Source: Congressional Budget Office 2009

According to the Act $37 \%$ of the stimulus bundle were dedicated to tax cuts equaling $\$ 288$ billion and $18 \%$ of the package is devoted to state and locate fiscal relief equaling $\$ 144$. The remaining $45 \%$ of the package were assigned to federal social and spending programs. For instances the allocations depicted above in the bubble diagram. Education and training was $\$ 53$ billion, energy $\$ 43$ billion, infrastructure and science $\$ 111$ billion, health care $\$ 59$ billion and protecting the population $\$ 81$ billion. All of the allocations outlined are driving focuses that impact the economy and important issues to the American people. 
Figure 4: Composition of the Funding Allocation under the American Recovery and Reinvestment Act, of 2009
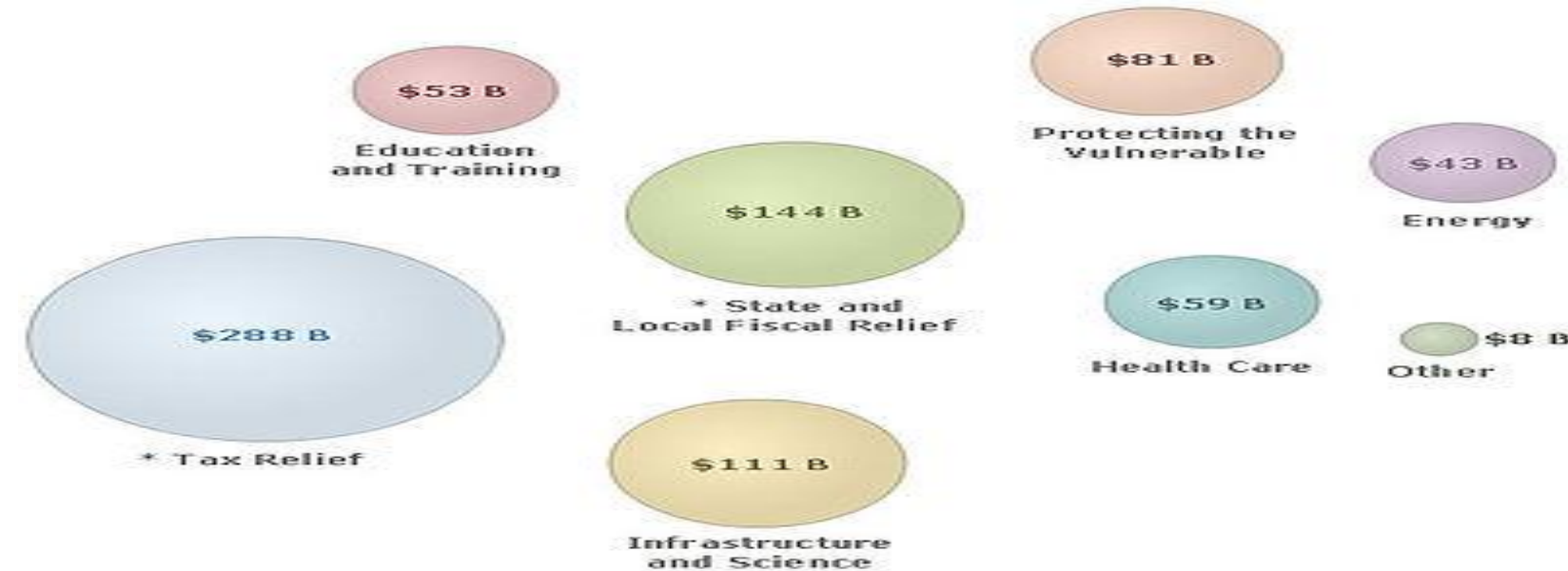

Source: http://en.wikipedia.org/wiki/File:Investmentbubble.jpg

\section{Conclusion}

America is facing an economic disaster and is in need of federal relief to remain leading nation. Is America currently facing another Great Depression? The uncontainable depression later referred to as the Great Depression attacked the economy of the United States. In 2007 the United States began to take an economy downtown again. President Franklin D. Roosevelt implemented the New Deal Programs to recover the economic damage of the United States. President Barack Obama inherited a stressed economy from former President George W. Bush with a national debt of \$10.627 trillion. As President Roosevelt once did, President Obama is now working toward a plan to recover the damaged United States economy. There are a number of lessons learned from President Roosevelt that should have been put into action long before the United States encountered another economic downturn. Although President Roosevelt's Economic Bill of Rights was not enacted into legislation, President Obama can utilize Roosevelt's experience as a foundation for address today's economic downturn. President Roosevelt was able to restore the economy of the United States with the implementation of the New Deal Programs. President Obama is now working toward restoring the failing United States economy once again with the implementation of the American Recovery and Reinvestment Act of 2009. The proceeding graphs and charts will provide comparative analysis on American during the Great Depression and America now.

\section{Recommendations}

Therefore, the following recommendations are proffered:

- First, just as President Obama and President Franklin D. Roosevelt, there must be an intervention and deployment of strong and active fiscal measures through the Act of congress to strengthen the American economy, businesses and people in the face of economic downturn.

- Second, this paper suggested that as in the New Deal programs, government must offer a way out of the economic crisis by provide relief with a broad program that involve a level of policy planning and coordination that was beyond the capacity of the Congress.

- Third, successive administration must have stimulus package of economic programs to relief unemployed individuals reform businesses and their financial practices and promote recovery during the economic depression.

- Finally, the elements of the Recovery Act that measured to be effective should be extended upon current programs and financing streams at the state and local levels for the implementation of the 2020 Stimulus. 


\section{References}

American Recovery and Reinvestment Act of 2009. (2009). Wikipedia, 1-17.

The Great Depression, to 1935. (1935). 17 Apr. 2009 <http://www.fsmitha.com/h2/ch15wd.html>.

On the job front, still no Great Depression, but getting a little closer - The Curious Capitalist - TIME.com. The Curious Capitalist - TIME.com - Commentary on the economy, the markets and the strange ways of business. 5 Apr. 2009 <http://curiouscapitalist.blogs.time.com/2009/04/07/on-the-job>.

Organizing for America | BarackObama.com. 30 Mar. (2009). <http://www.barackobama.com/2007/09/17/remarks_of_senator>.

Patterson, T. E. (82). Federalism: Forging a Nation. The American Democracy. 6th Ed. New York: McGraw Hill, 2003. 81-83.

Pursuit of Happiness. (1939). TIME 16 Oct. 1939.

Roosevelt, President Franklin D. (1900-1945). The Rise of the Positive State: 1900-1945: An Economic Bill of Rights (11 January 1944). American Political Thought. Ed.

Kenneth, M., Dolbeare. \& Michael, St. (2004). Clair Cummings. 5th ed. Washington, D.C: CQ P, 418-20.

The Roosevelt Week - TIME. Breaking News, Analysis, Politics, Blogs, News Photos, Video, Tech Reviews TIME.com. 30 Mar. 2009 <http://www.time.com/time/magazine/article/0,9171,743953,00.html>.

Rothbard, M. N. (2000). America's Great Depression. 5th ed. Auburn: The Ludwig von Mises Institute, 2000.

The world economy is tracking or doing worse than during the Great Depression | vox - Research-based policy analysis and commentary from leading economists. (2009). Front Page | vox. 30 Mar. 2009 <http://www.voxeu.org/index.php?q=node/3421>. 